\title{
Л.Ф. Алексеева
}

Московский государственный областной университет, 141014 г. Мытищи, Московская область, Российская Федерация

\section{Память о любви и смерти в повести Н.В. Болкунова «Дорога домой»}

Аннотация. Цель статьи - привлечь внимание к поэтике художественного времени и пространства в повести о Великой Отечественной войне, написанной в XXI в. Автор «Дороги домой» Николай Васильевич Болкунов (1948-2010) сам войны не видел, но глубоко осмыслил ее суть, сделал акцент на нравственном противостоянии защитников русской земли и разрушающих ее немецко-фашистских захватчиков, уверенных, что им удастся разорвать связи между поколениями, превратить покоренное население в потребителей материальных благ, родства не помнящих. Герменевтический подход к тексту (выявление духовной составляющей) ведет к выделению особо значимой для автора проблемы преемственности, взаимоотношений между поколениями и менталитетами, анализу характеров, авантюрно-приключенческих и занимательных элементов, любовной «линии», трогательных и трагических ситуаций, пейзажных зарисовок, бытовых и натуралистических деталей. Последовательно выявляется перекличка военных и послевоенных обстоятельств, определяющих создание широкой исторической картины, цельность которой придает максимальная приближенность автора к психологии лейтенанта Минаева, спустя несколько десятилетий ставшего стариком Михалычем. Пронзительно трагический сюжет целомудренной любви освещает память, всю жизнь главного героя, определяет его внутреннюю установку на укрепление добра, стойкость в защите человеческого достоинства. Эпизоды произведения рисуют образ врага-разрушителя, лишившего многих наших соотечественников крова, светлой юности, любви, здоровья, самой возможности жить. Анализ художественного текста сочетается с привлечением биографических, литературоведческих материалов. Сделан вывод о том, что повесть имеет несомненный педагогический потенциал и может быть рекомендована для чтения и изучения учащимися старших классов, студентами высшей школы и средних специальных учебных заведений.

Ключевые слова: повесть Н.В. Болкунова «Дорога домой», трагический сюжет произведения, герменевтический подход к изучению художественных текстов, проблема разрыва преемственности, словесный пейзаж, историческая и психологическая достоверность в повествовании XXI века

\section{L.F. Alekseeva}

Moscow Region State University, Mytishi, Moscow Region, 141014, Russian Federation

\section{Memory of love and death in N.V. Bolkunov's novel "The road home"}

Abstract. The purpose of the article is to draw attention to the poetics of the artistic time and space in the story of the Great Patriotic War, written in the XXIst century. The author of "The Road Home" Nikolaj Bolkunov (1948-2010) did not see the war himself, but deeply understood 
its essence, emphasized the moral confrontation of the defenders of the Russian land and Nazi-fascist invaders destroying it, confident that they will succeed to break the ties between generations, to turn the subdued population into consumers of material goods, into those who are oblivious to their kin. Hermeneutical approach to the text (identification of the spiritual component) leads to identifying an issue, particularly significant for the author, the issue of succession, relationships between generations and mentalities, analysis of characters, adventurous and entertaining elements, love plotline, touching and tragic situations, landscape sketches, everyday and naturalistic details. Consistently revealed the roll call of military and post-war circumstances, determining the creation of a broad historical picture, the integrity of which is obtained due to the author's closest proximity to lieutenant Minaev's psychology, who became a few decades later an old man, Mikhalych. The piercingly tragic plot of chaste love illuminates the memory, the whole life of the main character, determines his inner setting to strengthen good, resilience in the protection of human dignity. Many episodes of the work paint the image of the enemy-destroyer, who deprived many people of our fatherland of shelter, bright youth, love, health, the very opportunity to live. The analysis of the text is combined with the involvement of biographical, literary materials. It is concluded that the story has an undoubted pedagogical potential and can be recommended for reading and studying by high school students, students of higher and further education institutions.

Key words: N.V. Bolkunov's long short story "The road home", the tragic subject of the work, hermeneutical approach to the study of fiction, the issue of a succession gap, a verbal landscape, historical and psychological authenticity in the narrative of the 21st century 